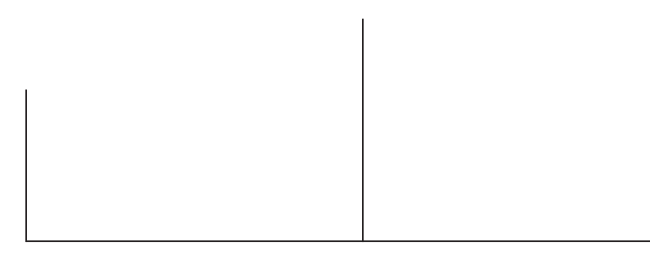

Rev. Latinoam. Psicopat. Fund., III, 3, 46-72

\title{
Quais (im)posturas intelectuais? O erro de Darwin
}

Pascal Mettens e Roland Gori ${ }^{1}$

\begin{abstract}
Neste texto busca-se uma teorização do sujeito a partir da psicanálise, do estruturalismo e da noção de pós-modernidade.

Os autores propõem-se, aqui, a mostrar como e por que um ocultamento da questão do sujeito incessantemente retorna e conduz às piores derivações ideológicas, diluída que é e em um corpo cujo espírito se vê reduzido a uma função entre outras ou na massa de indivíduos orientados para um fim comum, eventualmente conflitual. E tomam como hipótese "demonstrar que toda disciplina projeta sobre a maneira em que se desenvolve 'sua' ciência a epistemologia implícita com a qual freqüentemente se sustenta à sua revela”.
\end{abstract}

Palavras-chave: Psicanálise, teorização do sujeito, estruturalismo, pós-modernidade

1. Universidade de Provence (Aix-Marseille I). Salvo menção contrária, os grifos são dos autores.

Tradução de Dirceu Scali Jr. 


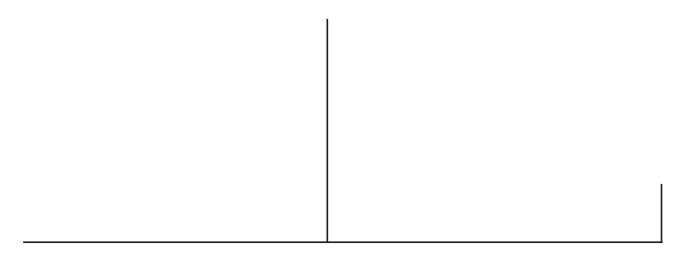

Visão de conjunto: o caráter ambíguo de nosso mundo moderno - os próprios sintomas podem indicar degradação e vigor.

E a propósito da verdade: "Uma multidão efervescente de metáforas, metonímias, antropomorfismos”.

Nietzsche (apud Zima, 1994, pp. 26 e 28)

Em um trabalho anterior (Mettens \& Gori, 1998), mostramos, em resposta às Imposturas intelectuais de Sokal e Bricmont, como a questão da linguagem é fortemente ocultada pela da escrita, quer seja "literária" ou matemática, e na qual as relações entre lógica e pensamento permanecem problemáticas a tal ponto que seria um suicídio epistemológico não considerar a existência de um construtivismo estritamente cognitivo, distinto do processo de leitura e de escrita, e impedindo todo acesso imediato ao que alguns denominam muito ingenuamente os "fatos" ou a "natureza". Admitimos que a ciência, e de uma maneira geral todo pensamento, não é redutível sem distinções a uma construção narrativa, porém não excluímos a possibilidade de que uma certa realidade simbólica determina o pensamento.

A questão do estatuto epistemológico do conhecimento, o conhecimento científico entre outros, não é pois resolvida. É porque, após ter abordado a do objeto, dessa vez é o problema do sujeito da ciência que gostaríamos de tratar sob o ângulo indireto de duas disciplinas que surgiram, quase ao mesmo tem- 


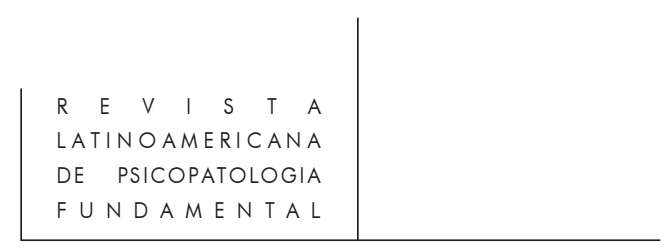

po, na virada do século XIX, e determinam cada vez mais fortemente nossas concepções atuais: trata-se certamente da biologia e da sociologia. Propomo-nos, aqui, mostrar como e por que um ocultamento da questão do sujeito - termo que teremos de definir - incessantemente retorna e conduz às piores derivações ideológicas, diluída que é em um corpo cujo espírito se vê reduzido a uma função entre outras ou na massa de indivíduos orientados, ninguém sabe muito como, mas cada um está convencido disso, para um fim comum, eventualmente conflitual.

É, pois, com a ajuda da psicanálise, do estruturalismo e da noção de pós-modernidade, que tentaremos ao final de nossa reflexão mostrar a necessidade de uma teorização do que chamamos o sujeito, único meio, acreditamos, de pensar as questões da troca e da comunicação na/pela linguagem e palavra.

Nossa hipótese de estudo será a seguinte: procuraremos demonstrar que toda disciplina projeta sobre a maneira em que se desenvolve "sua" ciência a epistemologia implícita com a qual freqüentemente se sustenta à sua revelia. Essa ignorância reconfortante do que a funda conduz a encontrar as faculdades próprias desse sujeito, que permitem apenas apresentá-la na aparência exterior da situação ou do evento em que tem a ilusão de se inscrever, sejam esses "eventos" biológicos ou sociológicos. Nessas condições, as noções de modernidade e de pós-modernidade permanecem eminentemente ideológicas e determinadas pelo ponto de vista que assumem seus partidários ou detratores sobre os objetos específicos de pesquisa geralmente trata-se das mesmas problemáticas, mas abordadas diferentemente. Esse ponto de vista, quando não é explicado, infelizmente contamina até a estrutura da comunicação científica e escande de maneira artificial as revoluções que aí se produzem.

Se a teoria do conhecimento, da qual tratamos precedentemente, é uma "descoberta" da filosofia desde a Renascença e expande-se à época clássica, atravessada pela questão da exatidão, da dúvida e da verdade, a história, por outro lado, no sentido que atualmente entendemos, entra nas preocupações da filosofia somente no século XIX (Mettens, 1998a) - antigamente ela era apenas natural. A palavra biologia é com efeito forjada apenas em 1802 (Bloch \& von Wartburg, 1932; Rostand, 1945; Foucault, 1966. Ver também os comentários de Del Volgo, 1997; p. 103). Em 1804, ou seja, quase simultaneamente, Hegel, vendo Bonaparte passar após a batalha de Iena, sente soprar o vento da história, que sabemos determinará profundamente seu sistema filosófico e marca o fim da filosofia representacionalista dos clássicos. Cerca de vinte anos mais tarde, quando muito, influenciado por seus predecessores Saint-Just e Condorcet, Comte forja o termo sociologia e institucionaliza um conhecimento do qual trata, a partir de então, menos de pensar os fundamentos que de organizá-los para que reorganize a sociedade e a conduza a seu estado positivo terminal (Comte, 1822, 1825, 1830; ver também nosso comentário anterior: Mettens \& Gori, 1998). 


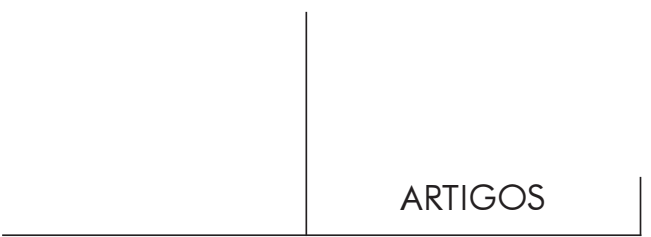

Sob a bandeira da ordem, do progresso ou da síntese, a história, humana ou natural, ocupa pois um lugar central na filosofia sob formas diversas e, às vezes, convergentes da dialética, do darwinismo, da sociologia ou do marxismo, para citar apenas essas. $\mathrm{O}$ objeto, a idéia, o fenômeno teriam sido anteriormente retirados da metafísica que, de uma maneira ou de outra, conservaria o domínio do que Kant chamava o supra-sensível. É dessa vez a intangibilidade do ser e a própria noção de essência que a ciência vai se apropriar buscando materializá-la em um substrato localizável. Assim, conviria, com Canguilhem, que

... jamais diremos suficiente que peso teve na história da biologia a utilização, por Aristóteles, do termo organon para designar a parte (morion) funcional de um corpo animal ou vegetal, assim como mão, bico, asa, raiz etc. Até o fim do século XVIII, ou menos, a anatomia e a psicologia conservaram, com seu poder de equivocidade, um termo que Aristóteles emprestou do vocabulário dos artesãos e dos músicos, e cujo uso supõe a adesão, implícita ou explícita, a alguma idéia de analogia, em qualquer sentido que o tomarmos, entre a natureza e a arte, entre a vida e a técnica. (Canguilhem, 1993; p. 124)

A noção de órgão é, pois, apresentada elevada à dignidade de promover o conceito de um lugar teleológico da unidade mínima do ser corporal em estado de constituir ulteriormente um obstáculo epistemológico ao reconhecimento dos trabalhos bioquímicos, teciduais, celulares e moleculares. Nessas condições, as questões da alma e do sujeito ver-se-ão dissecadas à luz das ciências naturais ou do espírito em função de pressupostos ideológicos de cada modo particular de conhecimento, não sem cada uma correr o risco de reatar com a metafísica e sua preocupação de circunscrever o lugar do ser, ora no sentido da história, ora nos processos do ser vivo. E de devires históricos e/ou evolucionistas, essas ciências não mais hesitarão em estatuir elas próprias sobre seu destino e sua condição, colocando simultaneamente nos próprios termos a questão da especificidade, não mais de seu objeto, mas do sujeito conhecedor que assim os permite.

As ciências contemporâneas, aliás, reatam atualmente com essa sucessividade de paradigmas, já que a mecânica quântica, que alguns neodarwinistas não hesitam mais em qualificar de espantalho (Edelman, 1992) se vê progressivamente substituída por uma biologia entendida como a nova "matriz essencial do conhecimento científico" (Gori, 1997). Esses são alguns dos paradigmas que examinaremos aqui de maneira crítica, a fim de pôr em evidência a ideologia implícita que os subentende e condiciona a maneira pela qual a ciência se situa - mas ela está habilitada? como instituição social e instância simbólica.

Devemos esclarecer que definimos com Canguilhem a ideologia científica como

“... o desconhecimento das exigências metodológicas e das possibilidades operatórias da ciência no setor da experiência que ela procura investir, mas não é senão a 


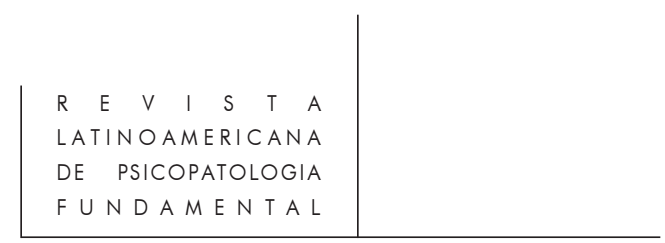

ignorância, ou o desprezo ou a recusa da função da ciência”. Por outro lado, essa formação discursiva que constitui a ideologia científica não deve ser confundida com as falsas ciências, nem com a magia, nem com a religião. Ela, como as outras, é movida por uma necessidade inconsciente de acesso direto à totalidade, mas é uma crença duvidosa na direção de uma ciência já instituída, da qual reconhece o prestígio e da qual busca imitar o estilo.

O sintoma da ideologia científica reside em sua gênese, sua função, sua estrutura com pretensão a dar conta de questões fortemente saturadas por uma formulação metafísica a partir de dados fenômeno-técnicos parciais, mas rigorosamente validados. A ideologia científica procede então pelos meios figurativos que a linguagem põe à sua disposição, quer se trate de metáforas ontológicas ou de metonímias para esquecer o que os dados do conceito ou dos fenômenos experimentais devem aos contextos e aos dispositivos que os produzem. É essa ilusão transcendental que indica Canguilhem quando escreve: “... nesse sentido, a ideologia é o conhecimento ainda mais distanciado de seu objeto ao qual acredita estar unido; é o desconhecimento, uma vez que um conhecimento crítico de seu projeto e de seu problema se sabe inicialmente a distância de seu objeto operatoriamente construído". (Canguilhem, 1993; pp. 39, 44-5)

\section{O darwinismo: uma seleção cultural?}

Começaremos por evocar a biologia, na medida em que o paradigma darwiniano, que atualmente dizemos ser um suicídio intelectual contestar, tem direta e duravelmente influenciado muitas correntes de pensamentos, do mesmo modo como anteriormente a física newtoniana reinou com exclusividade sobre o conjunto dos domínios do conhecimento. Mas da mesma maneira que o heliocentrismo ia retardar e frear a elaboração e a aceitação do darwinismo, esse último ia constituir uma resistência ao reconhecimento das teorias mendelianas em ciências da vida.

É certamente sobre um ponto da introdução do primeiro trabalho de Darwin que concretiza uma intuição ultrapassada de vinte anos que nós nos deteremos, seja a explicação da origem das espécies por via da seleção natural pela luta pela existência na natureza. Que os termos natureza e existência sejam aqui unidos é de interesse primordial para uma explicitação das relações a nosso ver problemáticas, mas sempre homonímicas que existem em muitas das disciplinas entre corpo, cérebro e espírito.

Esses comentadores, em geral, raramente assinalam que a Origem das espécies de Darwin (1859) se abre para a declaração da fonte da inspiração mais determinante de seu autor: não se trata tanto da viagem no Beagle que lhe permitiu ver tantas espécies desconhecidas e de se iniciar na geologia (Mayr, 1982; 532 e 


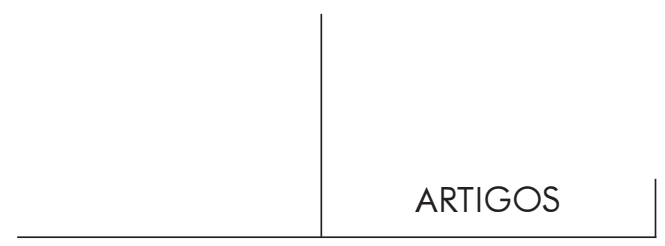

548 s.), mas de deduções tiradas da observação dos processos de seleção efetuados de maneira tão intuitiva quanto eficaz após séculos pelos criadores ingleses ${ }^{2}$. Nessas condições, a origem do darwinismo torna-se eminentemente problemática. Na verdade, além de sua paixão pela caça e a pesca em que apenas sobrevive o animal mais adaptado, além de sua leitura em 1838 do ensaio demográfico sobre a população de Malthus (Rostand, 1945; e Mayr, 1982; pp. 532 e 546) que consagra um liberalismo inglês em pleno desenvolvimento, enquanto aceitava já na seqüência de Lyell a idéia de uma concorrência entre as espécies, Darwin funda sua intuição, verdadeiramente luminosa, sobre a generalização ao conjunto dos seres vivos de uma técnica de cruzamento efetuado pelo homem.

É (...), escreve Darwin, da maior importância elucidar quais são os meios de modificação e de co-adaptação (das espécies). Pareceu-me, inicialmente, provável que o estudo atento dos animais domésticos e das plantas cultivadas deveria oferecer o melhor campo de pesquisas para explicar esse obscuro problema. Eu não fui, continua, desapontado; logo reconheci, na verdade, que nossos conhecimentos, por mais imperfeitos que fossem, sobre variações em condições de domesticidade, nos fornecem sempre a explicação mais simples e a mais sujeita ao erro. Que me seja permitido, conclui, acrescentar que, em minha convicção, esses estudos têm a maior importância e que são habitualmente por demais negligenciado pelos naturalistas. (...) O poder da seleção, de acumulação, que o homem possui, é (pois) a chave desse problema; a natureza fornece as variações sucessivas, o homem as acumula em algumas direções (e) cria para seu proveito raças que lhes são úteis. (Darwin, 1859; pp. 3-4 e 31 - grifos nossos)

De qualquer forma, a natureza propõe, o homem dispõe... ${ }^{3}$

A seleção natural é, conseqüentemente, a transposição analógica e a generalização dessa mortificação que impõe o homem aos seres vivos decretando quem viverá (se reproduzirá) ou não. A questão que se põe a seguir ao naturalismo inglês é, pois, a seguinte: “... quem é que na natureza poderia desempenhar o papel do homem, escolhedor, seletor de caráter? (...) O que, conclui, na natureza, substitui o homem, é a morte" (Rostand, 1945; pp. 143-145), a qual suspende a progressão geométrica examinada por Malthus (Darwin, 1859; p. 71). “A seleção natural (...), afirma Darwin, é uma potência sempre prestes à ação; potência tão superior aos frágeis esforços do homem quanto as obras da natureza são superiores às da arte" (ibid.; p. 67). Pois do ponto de vista da domesticidade, a seleção é considerada em uma

2. Essa leitura é contestada por Mayr (1982: 654 seqs.), porém esses argumentos não nos parecem nada convincentes.

3. O leitor notará a atitude sistemática de Darwin, coligando sua doutrina a um programa metafísico no sentido de Popper (1962). 


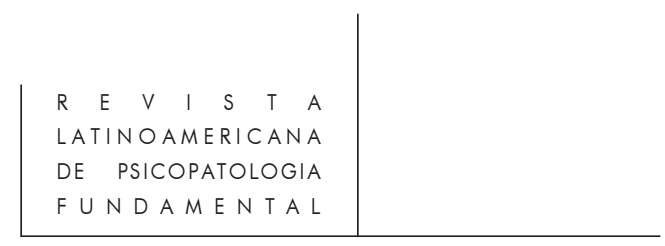

perspectiva técnica, adaptando-se muito bem a uma economia industrial, e a força da seleção 4 natural é explorada, "inconscientemente" ou "metaforicamente", como um meio de unir o útil - no sentido de utensílio - ao agradável. (Ibid.; pp. 44 e 34)

O meio utilizado por Darwin para fazer coincidir sua ficção de uma seleção cultural por domesticação com o "estado" de natureza é, aliás, nele próprio - e é isso o essencial - evolucionista. É preciso que em tempos mais distanciados os selvagens, esses homens em devir, tenham já recorrido a técnicas rudimentares de cruzamento e de seleção. "Como um selvagem, pergunta-se o naturalista inglês, poderia saber, assim que aprisionasse um animal, se esse animal era suscetível de variar nas gerações futuras?" Imaginemos, pois, com Darwin esse cenário catastrófico que não pode receber senão um desfecho feliz: "Se existem selvagens tão bárbaros para jamais pensar em se ocupar da hereditariedade dos caracteres nos descendentes de seus animais domésticos, pode ser entretanto que um animal, que lhe é particularmente útil, seja mais preciosamente conservado durante uma privação (...). Nesse caso, resultará numa seleção inconsciente". (Ibid.; pp. 18 e 36 grifo nosso)

É surpreendente ver nosso irmão inferior que é o primitivo invocado para atestar uma seleção natural que não parece se efetuar, senão pelo homem, ao menos a seu único proveito, já que "... está na natureza de cada homem tomar toda novidade em sua posse, por mais insignificante que seja" (ibid.; p. 39). A seleção se vê assim inscrita na natureza do homem.

Retornaremos, posteriormente, aos problemas engendrados por esse raciocínio circular. Evidentemente, precisamos tratar agora de uma questão mais urgente: a do próprio conceito de seleção e as relações que ele mantém com o finalismo aparentemente banido, entretanto, de um evolucionismo darwiniano estritamente mecanicista e, pois, aparentemente não teleológico.

Detenhamo-nos, pois, um instante no termo seleção, central no arsenal conceitual darwiniano e que não foi, aliás, nem um pouco unanimidade. O próprio Darwin hesitou longamente antes de recorrer a ele ${ }^{5}$, na medida em que ele subentendia a existência de uma escolha voluntária nos seres vivos, o que nega o autor, consciente contudo de recorrer a metáforas traindo um certo criacionismo agnóstico (ibid.; pp. 86-87). Seus tradutores franceses consideram quanto a elas, antes de introduzir o neologismo de seleção, utilizar o termo eleição. As duas palavras, herdadas do latim, são aliás sinônimas e significam na verdade o (ele) que melhor convém (para

4. Considerada aqui como uma autêntica instância idealizada essencialista. A metáfora ontológica não está longe.

5. O termo não foi, aliás, originalmente utilizado por Darwin: ele preferia a palavra triagem (Mayr, 1982; p. 648). 


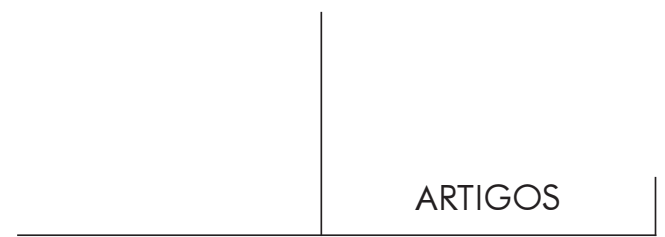

uma discussão, cf. Mettens, 1997; p. 152). A questão da existência e da (sobre)vida é, pois, no darwinismo imediatamente valorizado, e podemos nos surpreender que reside na própria origem desse pensamento antivitalista a questão, contudo, tão finalista da preferência ou da perfeição para a qual tende um comportamento ou uma forma. Não estamos longe da "biologia" perfeccionista kantiana, ainda tingida de teologia e de moral (cf., p. ex., Kant, 1786) ou das teses de Condorcet sobre a perfectibilidade do homem, apesar de o animal ter substituído a besta contra a qual luta desde Augustin o animal racional, seja o animal razoável que todos somos reputados ser.

Esse encontro, em pleno século XIX, da questão ética pela própria promoção do conceito de valor e a preocupação da epistemologia nascente sobre as ruínas da necessidade moral despojada nas ideologias científicas parece-nos sintomático. Se na época atual as tecnociências perseguem a dimensão ética que lhe falta, está na qualidade de herdeiras dessa clivagem em seus discursos, esboçado desde o século XIX, a preocupação com o bem e com o exato. A noção de normalidade nas ciências da vida constitui a formação de compromisso conceitual a mais reveladora em condições de conciliar essas duas correntes contraditórias. Canguilhem observa: "O vocabulário de Darwin, para quem toma ao pé da letra os termos seleção, vantagem, adaptação, favor e desfavor, mascara em parte a exclusão da finalidade na explicação darwiniana da origem das espécies. Quer dizer que está eliminada da idéia de vida toda referência a uma comparação de valores? Tornando mais preciso: "A nova ciência dos organismos vivos não apenas não limitou o aspecto normal ou anormal de seu modo de existência, mas ao contrário fundou-a, enraizando-a em sua estrutura originária" (Canguilhem, 1993; pp. 131 e 135). O encanto intuitivo de uma teoria científica frequientemente se vale do poder das metáforas que seus conceitos suscitam ou sobre os quais repousam. O debate em torno da própria tradução de selection por seleção, eleição ou triagem (cf. supra) testemunha a aposta retórica de uma teoria científica para aumentar seu poder cultural, achar-se acolhida por uma visão do mundo e integrada ao melhor nos corpos das ideologias. A sedução operada pelas teorias neurocientíficas revela-se incontestavelmente sobredeterminada, mas não poderíamos subestimar o poder de encantamento exercido por uma doutrina que desculpa os sujeitos pelo que lhes acontece.

Essa danação das teorias científicas em dever se transformar cedo ou tarde em ideologias antropomórficas se manifesta evidentemente na teoria darwiniana no próprio encontro dos desejos de seu autor. Para dizer de uma maneira mais forte, nós desconfiamos que na origem das espécies reside somente ... o homem que, longe de ser o produto, seria apenas a causa, no sentido de que apenas ele seria capaz de pensar neles e de os manipular. É porque estimamos que uma teoria que tende a apresentar o humano como o produto da evolução não deveria pressupô-la em sua origem. Pois é difícil não admitir que a questão das espécies não seja outra coisa 


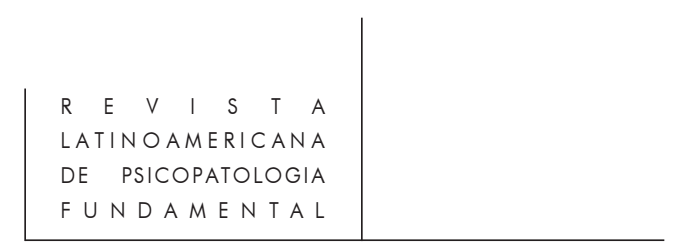

que uma realidade humana "artificial", mesmo quando o homem não faz mais que classificar o ser vivo em vez de o cruzar e o criar ou matá-lo - ainda aí, ele seleciona e exclui arbitrariamente. Encontramos essa última palavra em Darwin associada àquela de "vago" e ele observa "assim que dificilmente haja dois naturalistas que estejam de acordo para classificar essas formas como espécies ou como variedades"; é preciso pois freqüentemente apelar a "juízes" e se resolver por "classificar a maioria das vozes" (Darwin, 1859; pp. 52 e 50). ${ }^{6}$

A biologia é, pois, uma verdadeira torre de Babel, confrontada com a diversidade de línguas sábias que, contudo, em sua ficção não são ainda nascidas, e reunimos aqui o mito criacionista da Gênese, em que o ser vivo recebe por tarefa crescer e se multiplicar, enquanto o homem, além disso, é habilitado por Deus apenas para nomear - caçar, colher, domar, explorar, colecionar - as plantas e os animais que recobrem toda a superfície da Terra. Nessas condições, o darwinismo aparece apenas como um criacionismo laicizado em que a natureza, que seu autor, constatando, compreensivelmente, que "é muito difícil evitar de (a) personificar", recusa-se em definir de outra forma que como "a ação combinada e os resultados complexos de um grande número de leis ... naturais" (ibid.; pp. 87 e 84-85). Assim concebida, essa natureza é de maneira bem suspeita seu próprio criador sob o olhar espantado, mas nada passivo, do único ser vivo que seja capaz de se pôr a questão de sua própria condição.

Porque a Natureza, muito curiosamente, é personificada de ponta a ponta na Origem das espécies: existe, por exemplo, segundo Darwin, uma "economia da natureza" e o texto transborda de metáforas guerreiras - luta, destruição, guerra incessante em que se vence os concorrentes e em que se frustra os ataques para evitar que você mesmo seja destruído - em um mundo sem medo e quase idílico, já que a vida de seres vigorosos e indiferentes é sancionada por uma morte rápida (ibid., pp. 87 e 84-85). O que não impede as plantas de serem "verdadeiramente sociáveis" e "a seleção natural (de) modificar (os animais vivos em sociedade) a conformação do jovem em relação aos ancestrais" e vice-versa (ibid.; p. 56). Tudo está, pois, aparentemente para o melhor no melhor dos mundos... Pois a própria denominação de "economia da natureza" não é nem inocente, nem neutra. Ela “... autorizou, por dois séculos, a substituição, senão de bons procedimentos, pelo menos de más analogias, no estudo respectivo das leis dos corpos organizados e das sociedades humanas". "Mas de Linné a Malthus, a transição é tranqüila, e sem poder tomar a economia da natureza por uma doutrina pré-malthusiana da população, a extensão coloca ao homem e às suas sociedades questões relativas à ocupação

6. Observamos que a psicopatologia conhece esse gênero de taxonomia das espécies mórbidas cujo DSM-IV é atualmente o mais "digno" dos representantes. 


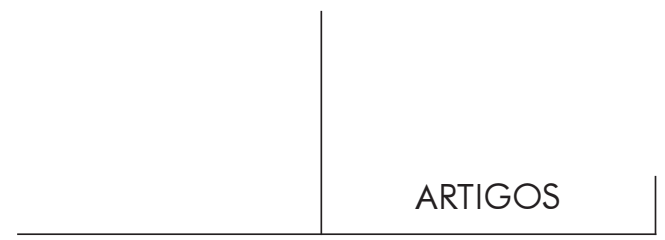

pelos seres vivos da superfície do solo terrestre e à qualidade de substância que eles aí podem encontrar. E é nesse ponto (que) os reguladores da ordem moral e os da ordem física (...) compõe(m) seus efeitos (Canguilhem, 1993; pp. 92 e 96).

Entretanto, a força de acumulação inerente à economia da natureza é eficaz apenas se for levada em conta na perspectiva de uma economia capitalista que explora as aquisições com fins de (re)produção. Com efeito, Darwin transpõe sociologicamente o isolamento geográfico à noção de cercado que segundo ele permite uma maior diversificação, enquanto os nômades, mais primitivos, em geral dispõem apenas de uma única espécie a qual lhes pertence como propriedade parti-

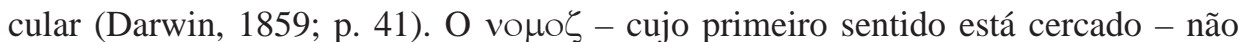
tem nada de natural que transforme o território em propriedade e é seguramente colocado pelo homem que delimita assim seus domínios, mesmo quando são balizados por obstáculos naturais. É, pois, tanto a questão sociológica da propriedade quanto aquela da denominação que é aqui fundamental para o humano que "é, lembremos, de sua natureza tomar toda novidade em sua posse, por mais insignificante que ela seja" e "escolher tendo em vista seu próprio benefício" (ibid., pp. 39 e 89). A biologia é, portanto, uma engenharia genética, ou antes uma bionomia, e isso antes mesmo que a descoberta da estrutura do DNA que permite manipular os seres vivos de outra forma que de maneira intuitiva.

Nessa perspectiva, o darwinismo existe apenas para justificar um homem capitalista, um industrial da criação. O que domina é o que é mais divulgado (ibid.; pp. 59-60)e é, por conseguinte, a maioria que freqüentemente leva a se reproduzir incessantemente e a estender para todos os lados sua hegemonia.

Eis como poderíamos, de maneira um pouco simplista e rápida, mas sem dúvida mais decisiva do que parece, senão invalidar, pelo menos contextualizar ideologicamente esse pensamento darwiniano tão caro a Popper (1962), já que se inspirou nele fortemente para defender sua concepção liberal da ciência, considerando-a, sem dúvida com razão, como infalsificável apesar de particularmente... fecunda. Certamente, Darwin é mais prudente e menos antropomorfo do que fazemos crer aqui e as reinterpretações propostas de sua teoria a partir do advento da biologia molecular são incontestavelmente mais prudentes e melhor asseguradas. Mas o problema, como veremos, subsiste ao estado endêmico em toda biologia contemporânea.

Para começar é suficiente ler atentamente algumas passagens da Origem das espécies para se dar conta de que persiste nessa natureza entretanto indiferente e aleatória na qual se procura transformar os seres vivos num demônio que "escolheu para ser ele mesmo (Darwin, 1859; p. 89), seja quem for que olha pelo que se exerce a preferência optimal para que subsistam os melhores adaptados e sobrevenham variações "úteis" ou "nocivas" à espécie (ibid.; p. 48). Tal é o caso, para tomar apenas esse exemplo, quando o pai do evolucionismo é confrontado com um pro- 


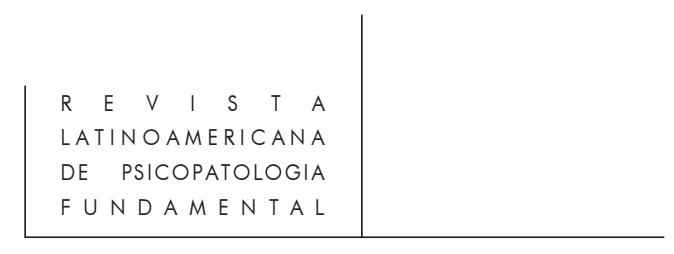

blema suficientemente complexo para deixá-lo entrever que essa força aparentemente cega que deveria ser a seleção natural é mais finalista do que parece.

Ouçamos Darwin:

A comparação do olho e do telescópio se apresenta naturalmente ao espírito. Nós sabemos que esse instrumento foi aperfeiçoado pelos esforços contínuos e prolongados das mais altas inteligências humanas, e concluímos disso que o olho deveria se formar por um procedimento análogo. Mas essa conclusão não é presunçosa? Temos o direito de supor que o Criador põe em jogo forças inteligentes análogas àquelas do homem? Se queremos comparar o olho a um instrumento óptico, devemos, precisa ele, imaginar uma camada espessa de um tecido transparente, embebecido de líquido, em contato com um nervo sensível à luz; devemos supor em seguida que as diferentes partes dessa camada mudam constante e lentamente em densidade, de maneira que se separa em zonas, tendo uma espessura e uma densidade diferentes, desigualmente distantes entre si e mudando gradualmente de forma na superfície. Devemos supor, por outro lado, que uma força, representada pela seleção natural ou a persistência do mais apto, está constantemente à espreita de todas as leves modificações afetando as camadas transparentes, para conservar todas aquelas que, em diversas circunstâncias, em todos os sentidos e em todos os graus, tendem a permitir a formação de uma imagem mais distinta. Devemos supor que cada novo estado do instrumento se multiplica por milhões, até que aí se produza um melhor que substitui e anula os precedentes. Nos corpos dos seres vivos, a variação causa as leves modificações, a geração os multiplica quase ao infinito e a seleção natural apodera-se de cada melhoramento com uma segurança infalível. Admitamos, enfim, que essa marcha continua durante milhões de anos e se aplique cada uma a milhões de indivíduos; nós não podemos admitir que poderia assim se formar um aparelho óptico vivo, tão superior a um aparelho de vidro quanto as obras do Criador são superiores àquelas do homem? (Ibid.; p. 199 - grifos nossos)

É, admitimos, muito curioso que a óptica, a qual está na origem das ciências físicas desde Galileu, com o telescópio, como da biologia com o microscópio (Rostand, 1945), seja assim considerada como um protótipo desse olho humano que tão decisivamente contribuiu para construí-lo! Todo o problema, apesar de em aparência banal, reside nessa surpreendente inversão que se vê tão freqüentemente quanto indevidamente explorada. $\mathrm{O}$ acaso da seleção natural é de fato tornado necessidade de progresso. A evolução exige, senão um Criador, pelo menos um anjo- da-guarda, pois sabe-se muito bem que Deus, após ter acabado sua obra, resignou-se a se repousar e a deixar crescer e se multiplicar suas criaturas.

Certamente encontramos a mesma dificuldade de crer em um tal Deus onipresente como aquele de Descartes que jamais dispôs de qualquer descanso sob a pena de que o sujeito do cogito, deixando-se enganar pelo sonho ou alucinação, não pudesse diferenciar o sonho da realidade (Descartes, 1641; t. I). É, pois, surpreendente que Darwin tenha sido enterrado ao lado de Newton, o qual contudo 


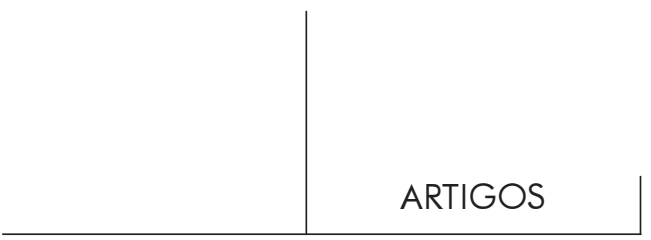

definitivamente autonomizou a física de toda forma de intervenção exterior e permanente, introduzindo a noção de vis inertia. Um corpo, em física, não mais precisa após a hipótese da existência de um princípio de inércia motora para persistir em um movimento retilíneo. A nosso ver, ainda hoje falta à biologia uma explicação interna, que não buscaria a ajuda de uma mãe-natureza exterior, guardando permanentemente o bom desencadeamento do programa aleatório dessa criação natural que "adota" curiosamente sempre os últimos caracteres adquiridos da tecnologia. Ainda aí, o conceito de normalidade traça uma linha de demarcação entre a epistemologia da física e aquela da biologia. "Entretanto acreditamos poder, em todos os níveis, identificar estruturas de ordem ao mesmo tempo fiáveis e falíveis. É para designar essa ordem que o conceito de normalidade é proposto. É um conceito que se convirá que é estranho à epistemologia da física. Seu uso delimitado não acarreta absolutamente a reprovação das bases físico-químicas da existência. Permite evitar a assimilação, pela economia de pensamento, de duas problemáticas históricas. (Canguilhem, 1993; p. 138)

Sem dúvida, irão nos objetar, e com razão, que o primeiro Freud (1895) foi confrontado com um problema análogo àquele do evolucionismo quando se viu constrangido, para explicar como funcionava a máquina neurônica construída por ele em vista de dar conta de processos de satisfação e de inibição, a formular a existência de um eu que seleciona constantemente as produções de um inconsciente bem indisciplinado para garantir a sobrevivência do indivíduo. Se a crítica tem fundamento, não se deve porém esquecer que o fundador da psicanálise se reivindicava Darwin, constrangindo seu aparelho psíquico a satisfazer às "exigências da (sobre)vida". O enigma que se colocava então à psicanálise era aquele da aquisição por esse homíneo que é filho dos patterns culturais que lhe permitiriam sobreviver em sociedade e lhe conferir o estatuto de humano.

Ninguém duvida de que as tópicas da psicanálise, como suas ficções metapsicológicas em geral, talvez não resistam à tentação das metáforas ontológicas. É mesmo em seu lugar que ela partilha com os outros modos de conhecimento o risco e a pretensão de se transformar em visão de mundo, em prejuízo de seu criador. O desvio metafísico consiste em transformar um problema fenômeno-técnico em enigma ontológico ao qual a generalização abusiva dos dados parciais e locais das ciências seria sensato fornecer uma solução.

Para Darwin, a questão que se põe é análoga: é legítimo reconhecer no termo da evolução natural as produções técnicas freqüentemente imperfeitas do homem?

Essa cultura "seletiva" posta a priori permanece onipresente na biologia contemporânea. Desde a descoberta de Mendel, as teorias probabilistas regulam de maneira imutável os cruzamentos e as produções de cada geração. Podemos nos surpreender que o monge austríaco, ele também especialista da cultura... das ervilhas que cruzou com paixão, tenha descoberto que a linguagem matemática era 


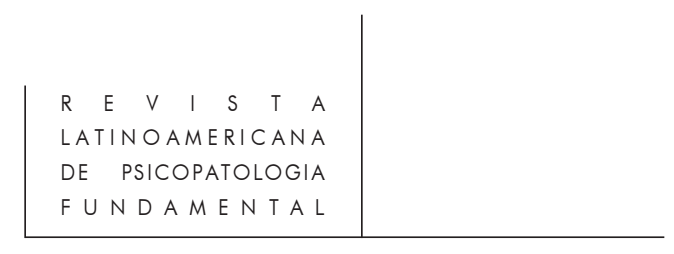

perfeitamente adequada para dar conta de fenômenos genéticos os quais ele não entendia ainda a "natureza". Da mesma maneira, com a importante descoberta da estrutura do DNA, são as noções de informação e de código, elas também probabilistas desde os trabalhos de Shannon, que são vistas expressas em termos de comunicação e de linguagem. As células tagarelam pois cada vez mais, e já trocam entre si informação. (Gagnepain, 1982; t. I)

Mas podemos nos perguntar se essa linguagem que reconhece a Evolução os biologistas são ávidos de maiúsculas ${ }^{7}$ - ao fim de seu curso estafado não é imprudentemente estabelecida desde as origens. Dizendo de outra forma, "após ter naturalizado o homem, a ciência não hesita em antropomorfizar o espermatozóide". (Gori, 1997)

Contrariamente ao que poderíamos pensar, o processo hegeliano não está muito distante, concebido como um "círculo retornando sobre si mesmo que pressupõe seu começo e o atinge apenas ao final" (Hegel, 1807; t. II, p. 306). Os biologistas, entretanto, alérgicos à história, certamente rejeitariam uma tal filiação. Mas podemos nos colocar a questão de saber se sua disciplina, definitivamente, não nos contaria senão histórias, antes de nos explicar em termos naturalistas - proeza à qual ela ainda não satisfez - como e quando emerge no homem essa capacidade que ele detém de historizar sua vida.

\section{Dialética e biologia}

A questão da dialética hegeliana, em que o processo contém desde o início seu próprio fim, não deixa de ter interesse para nossa proposta, na medida em que uma passagem ao limite da biologia, aliás muito justamente denunciado pelos neodarwinistas, exemplifica de maneira caricatural esse retorno "culturista" que acabamos de evidenciar no darwinismo. Certamente devemos a Rostand o fato de melhor ter percebido os riscos na época em que ele exerceu inúmeros danos nos meios científicos: trata-se, como podemos adivinhar, do mitchourienismo.

Rostand (1958) nos relata a aventura bem surpreendente dessa biologia destinada a satisfazer além-Berlim os apetites ideológicos stalinistas tão categóricos quanto imprevisíveis do pós-guerra. Isso não significa que o grande biólogo francês seja aqui suspeito de sustentar uma política capitalista de direita, em ciências como na vida pública. Muito ao contrário, ele reconhece a validade do marxismo ao qual não se sente capaz de aderir. É, sobretudo, a maneira pela qual é imposta uma biologia dialética por razões estritamente ideológicas que contesta com razão Rostand. Que

7. Evitando a navalha de Occam, alguns biologistas, pelo jogo de maiúsculas, elevam assim seus conceitos à classe de metáforas ontológicas. 


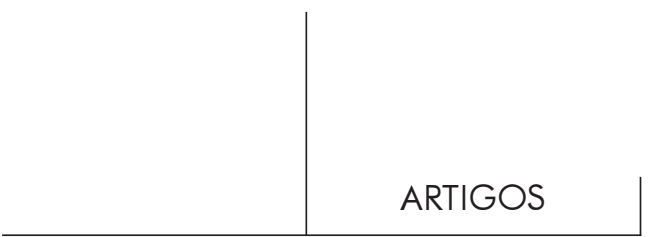

um Aragon, que um Waldeck-Rochet, respectivamente poeta e político, mas nada biólogos, tenham pregado a adesão às teses de Lyssenko o escandaliza com razão. O debate, bem entendido, pode parecer atualmente ultrapassado. Está claro que nem o stalinismo, nem o eurocomunismo são temas atuais na França, nem mundialmente. Mas tal não era o caso quando da redação do texto de Rostand, e veremos que a questão da ideologia subjacente à biologia darwiniana pode se revelar também problemática e inquietante, independentemente da "pureza" das intenções dos sábios para retomar um tema que lhe é caro. Essas boas intenções, aliás, conduziram também a alguns "desvios" desastrosos durante a Segunda Guerra Mundial em que infelizmente "inspirou" muito freqüentemente o nazismo e suas variantes européias. (Guillaumin, 1980; t. IX. Apud Darwin, 1859)

Mas retornemos a Rostand e à sua crítica da biologia marxista. $\mathrm{O}$ autor não é ingênuo a ponto de perder-se em um debate ideológico estéril. Ele repete, ao contrário, a inversão que transforma uma epistemologia, neste caso a da sociologia de Marx e Engels, em uma perigosa arma ideológica. O risco aqui, que fique bem claro, está em não buscar no exterior de uma disciplina os meios de fundá-la. Todo biólogo é pois intimado por Rostand - e não se pode senão dar-lhe razão sobre esse ponto - a buscar sem descanso um paradigma suscetível de ser reconhecido por outros biólogos como adequado a seu objeto: o ser vivo, ao qual notaremos de passagem que a biologia não nos propôs até esse momento definição coerente. ${ }^{8}$ Mas aos olhos do autor, e com ou sem razão, esse paradigma (não) é (senão) o darwinismo. Ele opõe pois duramente à afirmação que as teses mitchourienas “... decorrem dos princípios próprios do materialismo dialético - de Marx e (sobretudo) de Engels - no qual nós (quer dizer, os biólogos soviéticos e os membros do partido comunista) vemos o guia mais eficaz do pensamento científico". O problema aqui não é tanto contestar a validade do paradigma geneticista de Mendel ou evolucionista de Darwin, mas pôr em evidência as razões de um tal ostracismo: trata-se, segundo Rostand - e não podemos senão partilhar de suas reservas -, de uma "intoxicação doutrinária e ideológica". Com efeito, diante da ciência, a afirmação enfática de Aragon não mantém o caminho: "Jamais, escreve com fervor o poeta, (...) uma discussão científica terá se beneficiado de uma tal publicidade, assim não terá podido ser seguida por milhões de homens e de mulheres (...) Pela primeira vez o trabalho de um povo inteiro é associado à pesquisa científica".

Porque, assim "repensada", compreendemos que não é mais a biologia que explica e justifica a existência das sociedades humanas - o que constitui, entretanto, por meio da etologia, uma de suas pretensões legítimas ainda que sem dúvida 
ilusória -, mas ao contrário uma teoria sociológica e política que dita ao ser vivo suas próprias leis e transforma assim o mundo com o risco do delírio e da mistificação.

Evidentemente, podemos nos interrogar sobre a validade, e até mesmo, como fizemos, sobre a pertinência da hipótese darwiniana à qual não podemos subscrever sem expressar inúmeras reservas. Entretanto, apenas "fatos" biológicos são suscetíveis de falsificar essa teoria, é verdade de inspiração liberal e cuja extensão em política, dessa vez de direita, conduziu a excessos um tanto quanto discutíveis. Mas o que é essencial constatar é que a especificidade do objeto - o ser vivo - é no caso do mitchourienismo sacrificado à razão de estado. Do outro lado da Cortina de Ferro, é preciso que a biologia seja dialética para que o materialismo permaneça coerente. $\mathrm{O}$ antropomorfismo é aqui a regra, ao preço eventual, e manifestamente massivo, de uma contrafação de resultados.

Se é evidente que nenhum pensamento, mesmo científico, escape ao contexto no qual nasce, é inaceitável que o preconcebido toma passo sobre a "revolução" científica que consiste, não em gerar progresso como acredita ingenuamente Rostand, mas mais modestamente em remover as fronteiras do saber para tornar sempre recente um "velho" problema do qual somos apenas os herdeiros indisciplinados.

Nesse caso, trata-se sobretudo de colocar uma questão nos termos de uma teoria que lhe preexiste e que não está necessariamente adaptada ao seu objeto. "É uma verdadeira época da biologia - a primeira época da biologia que transforma ousadamente a natureza viva!", anunciam os intelectuais comunistas. Mas a biologia considerada do ponto de vista de seus riscos epistemológicos não deveria antes se deixar transformar pela natureza viva e buscar no organismo que ela observa uma resistência possível a toda autoridade eventual de seu dizer? E em que o homem, do ponto de vista da biologia, deteria uma posição privilegiada na série (in)definida do ser vivo?

Por outro lado, a crítica das teses darwinianas, se considerássemos, repetimos, que ela toma por objetivo o liberalismo e o capitalismo anglo-saxões, está calcada sobre a "revolução" marxista: o darwinismo é, na verdade, sobretudo suspeito de idealismo. É porque Waldeck-Rochet anuncia que "a metafísica e o idealismo filosófico são um entrave ao desenvolvimento da ciência, enquanto o materialismo dialético constitui um instrumento possante para fazê-la avançar". Não é espantoso constatar aqui o caráter a esse ponto vetusto dos debates? Além das oposições capital-proletariado, é precisamente o discurso de Marx (1875, p. ex.), já velho, como o de Darwin, de cem anos, que se encontra aqui reatualizado. Na verdade, o autor de $O$ capital não se afirmava como aquele que ousou inverter a dialética hegeliana desidealizando-a? Essa dialética é assim diluída na totalidade do mundo e explora a partir de então todas as forças vivas disponíveis, aí compreendida aquelas que não são humanas. O fim, em política, justifica os meios. 


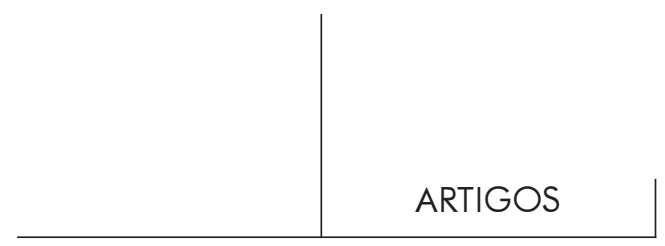

Porém, mais paradoxalmente, e isso é tudo o que dele reteremos, vemos aqui se desdobrar de maneira epistemologicamente perigosa a própria questão da evolução. Por um lado, notamos o aparecimento ao acaso no ser vivo de um homem que não estamos longe de considerar como o produto imprevisível definitivo de uma história monótona e sem fim; por outro, ratificamos com uma satisfação suspeita o nascimento de um pensamento do ser vivo pelo homem, único capaz de criar o mundo no qual ele está inserido mas, para que jamais coincida com ele, que tenta ilusoriamente transformar.

O darwinismo não escapa a um tal dualismo. É, por exemplo, surpreendente ouvir alguns biólogos, tais como Monod, reivindicar um logicismo chomskiano inatista e sacralizar uma linguagem que apenas deveria ser biologicamente um produto entre outros da evolução (Monod, 1970) ${ }^{9}$. Não é precioso ver aí a convicção antidarwiniana de um intelectual refinado, para o qual o pensamento permanece, apesar do bom sentido biológico, a função a mais superior que seja, mesmo que o espírito não devesse deter nenhuma superioridade de não ser desde Darwin mais que uma das funções dentre outras do corpo? Os efeitos de enfeitiçamento do nosso entendimento pela linguagem são, ainda aqui, manifestas.

Esse desdobramento da questão do ser vivo está assim na origem de uma metabiologia finalista que, como a metafísica na física - nós a mostramos anteriormente (Mettens \& Gori, 1998) -, contradiz os próprios princípios que a permitem formular. Assim como uma metafísica residia - e reside ainda - indevidamente no âmago da física, da mesma maneira, uma concepção do homem considerado como ser superior contamina uma biologia à qual uma tal questão deveria ser totalmente estranha. O darwinismo, o que quer que pensem seus partidários, logo que transpõe à sociologia a questão da espécie, torna-se um racismo generalizado ao conjunto dos seres vivos. Transposto ao homem, uma tal universalização estandardizante flerta perigosamente com a questão do sobre-humano apesar de, muito curiosamente, nenhum dos biólogos mais obstinados não serem por isso politicamente suspeitos.

Para começar, reconhecemos que esses biólogos, que abordaram com lucidez a questão da epistemologia de sua disciplina, entendem e afirmam sem ambigüidade o caráter cego dessa força - o termo não é sem importância - que é a seleção natural. O homem é o fruto de um só destino. Conhecemos a conclusão, que deu muito o que falar, formulada sem rodeios por Jacques Monod no final de sua obra mais conhecida do grande público: "O homem sabe enfim que está só na imensidão indiferente do Universo do qual ele emergiu por acaso. Não mais que seu destino, seu dever não está escrito em nenhuma parte. Cabe a ele escolher entre o Paraíso e as

9. É simplesmente a lingüística a mais próxima das teorias da informação na qual se nutre atualmente a biologia molecular. 


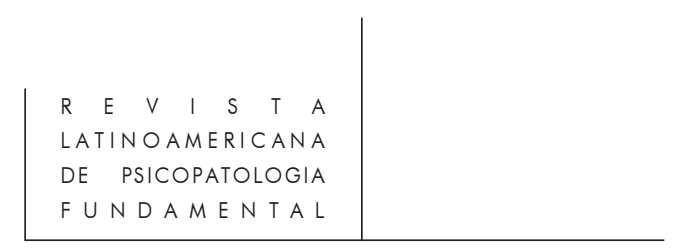

trevas" (Monod, 1970; p. 195). Rostand, uma dezena de anos antes, argumenta de maneira similar: "o homem, afirma ele, é um milagre sem interesse (...); a única altivez que (ele) possa pretender (é de) ser o que há de mais complicado como acoplamento de moléculas (...) (ele) não é nada menos que a obra de uma vontade lúcida, ele não é o resultado de um esforço surdo e confuso (...) Ele nasceu sem razão e sem objetivo, como nasceram todos os seres, não importa como, não importa quando, não importa onde. A natureza não tem preferências" (Rostand, 1954; pp. 202, 206 e 208). Entretanto, podemos perguntar por que subitamente se impõe a necessidade de uma tal recusa.

Porque, simultaneamente, o humano goza desse estatuto particular de ser "acidente entre os acidentes". Se "o homem sufoca no homem", "é ainda, assegura-nos Rostand, o animal que, no homem, recusa ser apenas um animal". Esse último, admitamos, tem as costas largas e nenhuma dúvida de que ele não confirmará ou desmentirá jamais as proposições do biólogo. Com efeito, o problema, tal como se põe o autor, é o seguinte: "a formiga não duvida que ela é apenas uma formiga; mas o homem sabe que ele é apenas o homem" (ibid.; pp. 202 e 208-209). Paradoxo surpreendente de uma superioridade humana que se exprime por um "apenas" e detém um caráter limitativo.

Monod não hesita em especular "metabilogicamente" sobre o milagre da linguagem que permite à evolução inclinar-se sobre si mesma e de "se" pensar. Pois é a questão da civilização que é infalivelmente enigma para a biologia e é a existência "imprevista" do homem que conduz a se colocar a questão do sobre-humano. É porque o biólogo se surpreende em evocar uma civilização humana ou sobre-huma$n a$ - descobertas, filosofias, ideais, religiões. (ibid.; p. 204 - grifos nossos)

A tentação, com efeito, é freqüente de chamar em socorro desse homínio esse sobre-humano e de transpor a questão das espécies à humanidade inteira. Mas, assim que examinada, a hipótese, é verdadeiramente perigoso, é no mesmo instante refutada. Porque a ciência não ouve dessa orelha e não projeta interrogar para além da biologia esse resto que ela não consegue jamais circunscrever. Na verdade, ela deseja permanecer essa "árida" e "rude doutrina" que foi "muito longe agora para se deter no caminho" - concepção, notamos, muito evolucionista do pensamento científico. Fica pois por juntar-se à ciência dos "métodos que preparavam as almas para recebê-la". Após ter bebido desde Comte do catecismo positivista, o homem pode enfim aceder ao batismo científico. "Não é mais suficiente, com efeito, assegura-nos Rostand, (que a ciência) nos mostre nosso nada, é preciso que ela nos torne capaz de o tolerar", "que ela regule o funcionamento de nossa máquina para que nos aceitemos como máquinas" (ibid.; p. 205). Certamente podemos nos perguntar se isso não é por estar confinado em uma ciência tão estreita que o homem apenas pode inevitavelmente sufocar.

Mas Rostand persegue imperturbavelmente: 


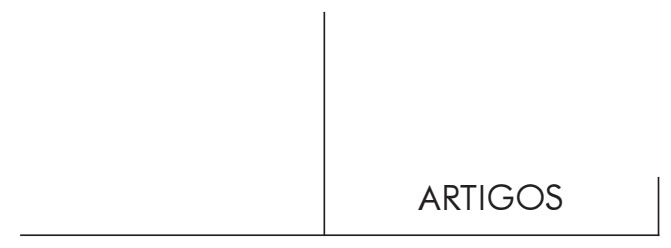

Poderia ser, por exemplo, que os progressos da fisiologia cerebral, ou simplesmente a psicanálise, (...) põem (o homem) em condições de modificar muito profundamente as reações psíquicas para que o indivíduo aceite as desarmonias inerentes de nossa liberdade, é preciso que ele regule o funcionamento de nossa máquina de tal maneira que nós nos aceitemos por máquinas. (Ibid.; p. 205)

Curioso destino de uma psicanálise aqui tingida de budismo, criada à orla do século por um Freud ainda darwiniano e higienista, mas progressivamente libertado de sua dívida em relação à civilização e ao desenvolvimento humano, e que se vê assim reduzida a uma biologia aplicada à educação das massas. Reich e Adler não estão muito distantes...

De certa forma, é interessante que a psicanálise seja aqui (enfim) nomeada, apesar de reduzida a um método educativo filiado à biologia, destinada a tornar o homem suportável para si mesmo. Aliás, é certo, nós o concedemos de bom grado, que uma das funções da cura consiste para cada um em assumir sua condição singular. Mas essa condição, lembramos, não é em nenhum caso predeterminado e universal, e nem certamente, de um ponto de vista, biológico. Para saber antecipadamente o que viveu o paciente, nós nos limitaremos, assegura-nos Freud, a recorrer a técnicas de sugestão (Freud, 1937). Aliás, é exatamente isso que nos propõe Rostand: uma psicanálise finalizada, afiada sobre a enteléquia do ser vivo.

Em compensação, o fundador da psicanálise não foi repelido pela biologia, apesar de se prejudicar por seu caráter "especulativo" (Freud, 1920; p. ex.), e talvez seja importante mencionar aqui que um projeto insensato animou-a durante alguns anos à instigação de seu discípulo e amigo Ferenczi. Tratava-se neste caso de relacionar as teorias de Lamarck, que permaneceram na Europa em concorrência com aquelas de Darwin até a década de 1920, com as aquisições da psicanálise. Mas Freud deixará Ferenczi só nesse projeto e o largará em proveito da construção mais essencial de sua segunda tópica. O psicanalista húngaro estava intimamente convencido de que uma biopsicanálise seria possível, considerando mesmo até a possibilidade de que cada órgão tenha sua própria personalidade ${ }^{10}$. Freud, mais preocupado com o reconhecimento científico e mais inclinado a levar em conta a dimensão incontornável da linguagem e da palavra em psicanálise, apenas procurou com um fim sem dúvida político chamar a atenção dos biólogos sobre a psicanálise. Ele permaneceu pois mais prudentemente no domínio do que chamava - apesar de que também disso desconfiava - a psicologia.

Por outro lado, é interessante comparar os destinos dos escritos de dois psicanalistas. Posto em dificuldades na redação de sua "Metapsicologia", que queria uma apresentação sistemática dos conceitos psicanalíticos, Freud se dobra sobre uma ficção mítica, pondo em cena a horda primitiva... noção darwiniana. Mas ele 


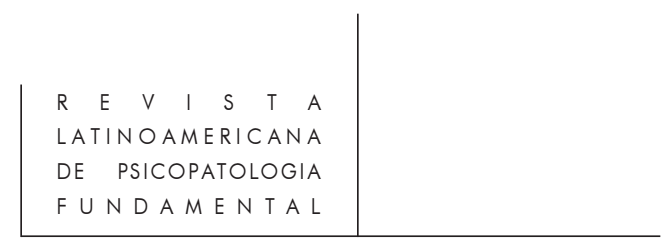

não regressa senão até a família originária impiedosamente dirigida pelo pai incestuoso (Freud, 1915) ${ }^{11}$. Ferenczi irá tentar um paralelismo filo-ontogenético (Ferenczi, 1924) remontando sem nenhuma vergonha até a célula primitiva, esperando encontrar na biologia as provas materiais, enquanto elas são no entanto "somente" simbólicas e de linguagem, dos processos postos em evidência pela cura (Gori, 1998b). Mas isso é uma outra história.

\section{Uma sociologia sem pessoa}

Insistiremos aqui sobre o fato de que a biologia não é a única responsável por esse ocultamento do humano no homem. Freqüentemente esquecemos que, bem antes de Darwin, a obliteração da psicologia foi empreendida por Auguste Comte. A sociologização do pensamento do qual procede, e que evocamos em outro lugar (Mettens \& Gori, 1998), é tal que a lógica torna-se sinônima da psicologia, e o sujeito prevalece definitivamente sobre o objeto. E se o homem clássico, como Descartes, sonha seu pensamento, já que é na saída de um sonho que ele começa a redação de seu "Método", ${ }^{12}$ o homem "moderno" mantém as afinidades com o delírio. É interessante, efetivamente, notar que é na saída de um internamento, manifestamente por causa de um acesso de paranóia delirante, que Comte, após ter consultado os tratados psiquiátricos de inspiração psicologista de sua época, elabora uma teoria do psiquismo em que singularmente está ausente o sujeito, no sentido clivado em que entende hoje em dia a psicanálise. Podemos, assim, considerar a obra de Comte como uma tentativa incessante de repetir, de arraigar esse delírio original na realidade social, com o risco de criar esta a partir do nada - de onde o caráter repetitivo e algumas vezes fanático de seu ensino. A religião positivista vai substituir, ela terá por função "regular" a existência individual, "reunir" diferentes indivíduos, para se tornar o "regulador" de um "organismo social".

Com efeito, Comte estima que o espírito não pode observar a si mesmo nem observar outros, na medida em que precisaria concebê-lo como suscetível de se dividir. Uma tal divisão apenas existe segundo ele na patologia e, como havia feito Descartes antes dele, retira a loucura de sua reflexão, devolvendo-a ao obscuro e ao irracional. "Mas o quê!, já exclamava Descartes, são loucos, e eu não seria menos extravagante se me pautasse por seus exemplos" (Descartes, 1641 ; t. I). ${ }^{13}$

11. Trata-se de "Visão em conjunto das neuroses de transferência", em que a referência à horda primitiva é logicamente, e não cronologicamente, proposta como uma solução a essa dificuldade.

12. Precedido, parece, de dois pesadelos os quais não cremos bom relatar os conteúdos porque eles não "teriam relação" com o conteúdo do "Método".

13. Cf. igualmente as observações de Foucault (1961). 


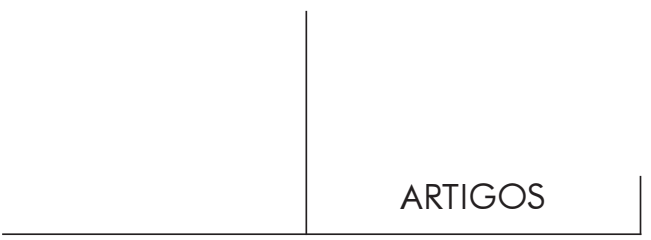

Restrição à qual Comte (1828; p. 402) $)^{14}$ iria mais longe afirmando que

... o homem pode observar o que lhe é exterior; ele pode observar algumas funções dos órgãos distintos do órgão pensante. Ele pode mesmo, até um certo ponto, se observar sob a relação das diversas paixões as quais prova, porque os órgãos cerebrais dos quais dependem são distintos do órgão observador propriamente dito, e ainda supõe que o estado de paixão seja muito pouco pronunciado. Porém lhe é evidentemente impossível observar-se em seus próprios atos intelectuais, pois o órgão observado e o órgão observante seriam, nesse caso, idênticos, por quem seria feita a observação? (....) Seria preciso, para que fosse possível, que o indivíduo pudesse se partir em dois, em que um pensaria e o outro, enquanto isso, veria pensar.

Ao mesmo tempo que a possibilidade de introspecção ou de auto-análise, os fenômenos patológicos, não apenas passionais, mas sobretudo intelectuais, são pois a priori rejeitados porque inaptos a permitir um estudo científico da psicologia do normal, no sentido da distinção das faculdades psicológicas. Não existe, conseqüentemente, para o positivismo nenhuma dissociação do sujeito, se não for patológico: o homem dispondo de todas suas faculdades não pode se auto-analisar, e o estudo da loucura dos outros não lhe é, nesse domínio, de nenhuma ajuda.

De ouvir Comte afirmar que o espírito do homem não pode ser um sujeito de observação, pois ninguém pode observá-lo nos outros nem em si mesmo, somos efetivamente tentados a concluir que nenhuma psicologia pode existir se não é ligada à fisiologia ou à sociologia. Nos dois casos o sujeito se confunde com o indivíduo, em uma expulsão dos efeitos de clivagem da linguagem e da palavra. (Gori, 1998a)

Apesar de que Freud e Saussure constituem tudo demarcando representantes importantes desse positivismo, e que a psicanálise freudiana permanece, o que quer que dela se diga, muito freqüentemente darwinista, está claro que o estruturalismo, que se inspira nesses dois pensadores, operou um corte radical com toda forma de naturalização das ciências do homem. Definitivamente não é mais o indivíduo que é apreendido como uma evidência. Já para Freud (1921) desde a introdução da segunda tópica, a psicologia social não pode ser distinta da psicologia individual. Para Saussure (1916), da mesma maneira, a língua é um sistema, certamente localizada no cérebro, mas que como instituição preexiste ao sujeito do qual não é senão o depositário.

Nessas condições, o princípio explicativo que preside à sociologia, à antropologia ou à psicanálise não é localizável em nenhum substrato material. As tópicas freudianas, decididamente antianatômicas ${ }^{15}$ são de certa maneira u-tópicas ${ }^{16}$. O in-

14. Para um comentário mais detalhado, cf. Mettens (1998b).

15. Mettens (1998a) contrariamente às teses de Assoun (1981.

16. Para retomar um termo de Gagnepain (1991). 


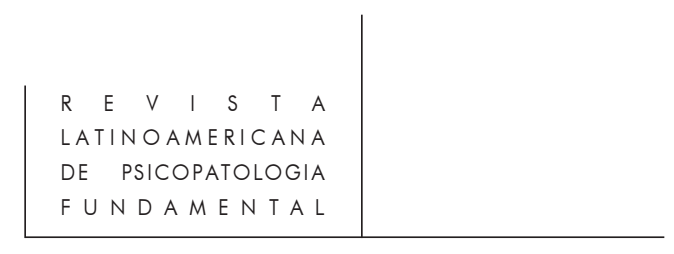

consciente lacaniano é, segundo ele, transindividual, análogo à língua saussuriana. $\mathrm{O}$ estruturalismo, contrariamente ao darwinismo como aos acessos historicistas, refuta pois toda pertinência explicativa à sucessividade de eventos: o inconsciente é desde então totalmente u-crônico. ${ }^{17} \mathrm{O}$ homem, entendido em sua especificidade de ser humano, não tem assim mais de localização (anatômica ou sociológica) que de idade cronológica. Tal é pelo menos o ensinamento da psicanálise e do estruturalismo, mas também da epistemologia, a qual exige a deslocação de seu proto-objeto empírico. Façamos nossa essa definição de Canguilhem: "Entendemos por objeto de estudo o material de trabalho, cuja história da ciência permite-nos estabelecer, uma vez mais, como o trabalho teórico-experimental da ciência, bem distante de encontrá-lo totalmente preparado". (Canguilhem, 1993; p. 11)

Antes que citar aqui as inúmeras reservas freudianas e lacanianas sobre a validade da explicação neuroanatômica, destacamos com Heidegger

... que não é preciso se espantar se, no interior da psicologia, nenhuma luz se faz no "lugar" em que são arrumadas as representações. Pois o organismo vivo, a consciência, a alma, o inconsciente e todas as profundezas e todos os patamares em que se subdivisa o domínio da psicologia, tudo continua repleto de questões. (Heidegger, 1951-52; p. 42)

Essas questões, contudo, parece-nos ter recebido algumas resposta pelo viés da psicanálise. Se Freud permanece darwiniano e se sua segunda tópica, muito personalista, coloca bem problemas sobre os quais é difícil reaparecer no espaço limitado desse trabalho, podemos considerar que o freudismo fez explodir progressivamente a noção de indivíduo. Da mesma maneira que o átomo da física clássica não passava de uma ilusão que a mecânica quântica rapidamente varreu, também, o indiviso, artifício no qual o biólogo e o etólogo criam ver se materializar as noções não apreendíveis do ser vivo ou da espécie, esse indivíduo não é indivisível pela psicanálise. O eu, equivalente dessa força que vigia permanentemente a seleção dos comportamentos adequados aos ideais, é com efeito desde Freud clivado em diferentes instâncias (Freud, 1932). Nessas condições, o humano jamais coincide com o homíneo, nem o sujeito - no sentido psicanalítico do termo - com o ser vivo que o abriga. O sujeito se revela indissociável pelo fato de a palavra fazê-lo acontecer como necessidade lógica em uma situação particular de interlocução em que somente sua hipótese circunscreve o "que falta à (sua) disposição para estabelecer a continuidade de seu discurso consciente. (Lacan, 1953; p. 258)

17. Retomamos essa palavra de Gagnepain (1991). 


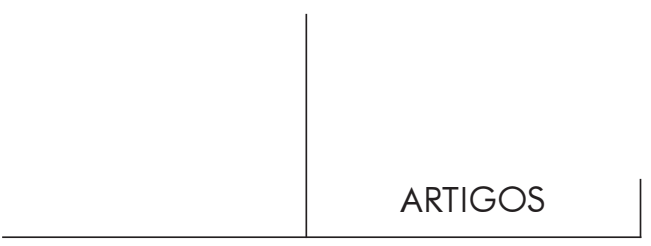

Conclusão: primeiro ou último homem?

“Os Tempos modernos escrito por Heidegger comentando Nietzsche, não estão de nenhuma maneira terminados. Eles, ao contrário, quando muito avançam em seu começo e sua realização será certamente longa" (Heidegger, 1951-52; p. 52). E esse homem moderno é a imagem da ciência a qual ele se dedica. A ciência dominante é atualmente a biologia e a concepção da história que defende desde então os sábios se inspira fortemente no evolucionismo e nesse positivismo que Lacan (1953; p. 260) notava que “... se seu papel é tão medíocre para o progresso científico, seu interesse se encontra contudo em outro lugar; é em seu papel de ideais que é considerável".

A ciência moderna veicula pois uma imagem de progresso, de vigor, de vitórias incessantes, e, se é preciso acreditar em suas declarações triunfantes, jamais esteve tão bem. Ela cresce assim de maneira malthusiana, progressão aliás inquietante para o biólogo que deveria talvez se perguntar qual seleção poderia regular essa proliferação incontrolável de variedades epistemológicas. Onde pois passou a seleção "natural" das idéias? Por outro lado, em um mundo científico tão estandardizado, o que é menos espantoso que a ciência seja atualmente unilíngüe, já que o arbitrário e o mal-entendido não existem em uma concepção biologizante em que são destinadas a reinar sobre o mundo inteiro os mais numerosos? E por ser numeroso, é preciso ser uniformes... Tal é hoje em dia o aspecto da comunicação científica.

Esse homem moderno, com certeza aquele das Luzes, a quem Nietzsche revelou essa convicção de um eterno retorno à orla da redação de seu Zaratustra. É o homem desprezável a seus olhos, que, depois que Deus está morto, apenas satisfaria o direito à felicidade e à igualdade anunciadas desde a Declaração dos direitos do homem. (Nietzsche, 1883; pp. 67-69)

"Se chegássemos a demonstrar que existe um órgão complexo que não pode se formar por uma série de numerosas modificações graduais e leves, reconhecia Darwin, minha teoria certamente não poderia defender-se" (Darwin, 1859; p. 200). Até o momento, parece que uma tal falsificação jamais seja produzida - o que é talvez inquietante quanto à eventual cientificidade da biologia. Mas essa não é nossa proposta.

Preferimos insistir à guisa de conclusão sobre o aparecimento desse paradigma mais recente, que denominamos estruturalismo, o qual recusou aderir a toda forma de evolucionismo e postula um corte radical entre natureza e cultura, refutando a explicação por uma história contínua pela emergência à arbitrariedade da linguagem. Esse homem estruturalista, que poderíamos qualificar de pós-moderno, está inclinado a considerar que a ciência não passa de uma produção cultural entre outras e a tratá-la como toda estrutura da linguagem, seja como um conjunto de elementos arbitrariamente extraídos do meio ambiente natural, do qual o homem é 


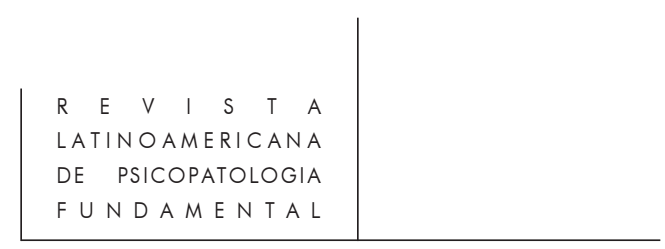

irremediavelmente cortado, apesar de ele jamais ter falado tanto disso. Que o racionalista se queixe não muda nada: a atitude é coerente no que ela obedece também aos princípios epistemológicos que presidem seu engendramento. As teorias científicas são, com efeito, desse ponto de vista estruturas narrativas. É suficiente, aliás, para disso se aperceber, estudar como fizemos o discurso da biologia, e as teorias científicas revelam-se tanto mais dependentes de sua textura narrativa que tendem a se extrair do contexto fenômeno-técnico do qual elas são tiradas funcionando como ideologias. Essas ideologias, ao prescreverem uma retidão do bem dizer e do bem pensar, inclinam perigosamente a uma normalização higienista das formas de vida, no sentido de Wittgenstein. Essa naturalização do humano reprimida sobre o ser vivo ejeta a clivagem da linguagem para ver reaparecer isso que ela nega sob a forma quase alucinatória do antropomorfismo da natureza. Duplo desconhecimento: por um lado, aquela do estatuto do sujeito falante; por outro, a da ausência de caráter moral ou teleológico dos processos físicos.

A epistemologia, com a condição de ser esclarecida simultaneamente pela história das ciências e uma prática concreta da pesquisa, poderia participar em estabelecer o cadastro dos discursos científicos, sua singularidade, seu ordenamento em série, sua degradação em ideologia, sua determinação lógica como sua subordinação à arte e à ética, sua transversalidade como suas regiões específicas, em uma palavra suas diferenças e suas semelhanças. Programa de uma semiótica diacrônica e sincrônica dos discursos de conhecimento e de sua estrutura formal.

A separação das ciências histórico-filosóficas das ciências da natureza constitui epistemologicamente uma aposta tida por alguns contra uma opção evolucionista totalmente defensável. Mas o homem pós-moderno, certamente mais cético que seu predecessor e fortemente influenciado por Heidegger, deveria lembrar-se de que também ele é confrontado com a questão do sobre-humano, posta por um Nietzsche, que já desconfiava dos sábios. Ora, contrariamente ao sobre-humano do biólogo, o que ensina Zaratustra não é, apesar de alguns derivados também lamentáveis, outra coisa "que uma ponte e não um limite", "uma corda estendida entre a besta e o sobre-humano - uma corda acima do abismo". (Nietzsche, 1883; p. 63)

Se falta ao evolucionismo uma teoria da narrativa que o projeta sem outra forma de processo no mundo exterior sob a forma ingênua da história natural, certamente o estruturalismo deveria por seu lado pensar mais radicalmente a relação que o humano mantém com esse animal que ele habita de um certo ponto de vista, sob a pena de não mais ser capaz de colocar, de outro modo que sob a forma da recusa, as relações entre gênese e estrutura.

É dizer resumindo que o crédito concedido pelo estruturalismo às formas simbólicas dá provas de uma substituição de uma decisão epistemológica subordinada a um contexto de experiências e de conceitos e não se prevaleceria impunemente 


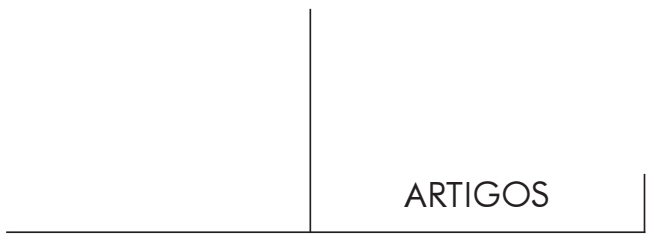

de uma prioridade ontológica. Sem o que o último recurso residirá na desqualificação dos adversários, quaisquer que sejam, caracterizados de pré-científicos.

É por isso que terminaremos citando Pavel:

Nessas condições e na ausência de toda argumentação, aplicar aos adversários a etiqueta de "pré-científico" equivale a pronunciar uma interrupção de morte simbólica, a traçar seu fim narrativo, fim que, ela, deve testemunhar do inevitável advento de um novo regime em antropologia. Tal é a força dos enunciados de expulsão. A retórica do fim dos outros exorciza o medo de ter de enfrentá-los, tranqüiliza as almas vacilantes, escoa no concreto da necessidade a contingência dos novos projetos, oculta o caráter incerto, precário, aventuroso, enfim o que precisamente em uma outra retórica os levaria a se tornarem sedutores, quase irresistíveis. (Pavel, 1988; p. 22)

\section{Bibliografia}

Assoun, P. L. Introduction à l'épistémologie freudienne. Paris: Payot, 1981.

Bloch, O. \& Wartburg, W. von (1932). Dictionnaire étymologique de la langue française. Paris: PUF, 1989.

BuytendJik, F.J.J. Psychologie animale. Paris: PUF, 1952.

Canguilhem, G. Idéologie et rationalité dans l'histoire des sciences de la vie. Paris: Vrin, 1993.

Comte, A. Lettre à Valat du 24.09.1819. In Carneiro, P.E. \& Arnaud, P. (eds.). Correspondance générale et confessions, t.I., 1814-1840, 51-61. Paris-La Haye: Mouton, 1973.

Plan des travaux nécessaires pour réorganiser la société. In Système de politique positive. Paris: Crès, 1822. t. X.

(1825). Considérations philosophiques sur les sciences et les savants. In Système de politique positive. Paris: Crès, 1912. t. X.

(1828). Examen du traité de Broussais sur l'Irritation. In Écrits de jeunesse. ParisLa Haye: Mouton, 1970. pp. 339-410.

(1830). Cours de philosophie positive. Paris: Schleicher, 1908. t. III

DARwIN, C. (1859). L'origine des espèces par voie de sélection naturelle ou La lutte pour l'existence dans nature. Paris: Maspéro, 1980. t. I.

Del Volgo, M. J. L’instant de dire. Le mythe individuel du malade dans la médecine moderne. Toulouse: Erès, 1997. [Trad. bras. O instante de dizer. O mito individual do doente sobre a medicina moderna. São Paulo/Goiânia: Escuta/Ed.Univ. Cat. de Goiás, 1998.]

Descartes, R. (1641). Méditations touchant la philosophie première dans lesquelles on prouve l'existence de Dieu et la distinction reelle entre l'ame et le corps de l'homme. Paris: Nathan (date ed. latin: a ed. franc. 1647).

Edelman, G. M. Bioligie de la conscience. Paris: Odile Jacob, 1992.

Ferenczi, S. (1924). Thalassa. Essai sur la théorie de la génitalité. In Oeuvres complètes. Paris: Payot, 1982. pp. 205-323. t. III. 
Foucault, M. (1961). Folie et déraison. Histoire de la folie à l'âge classique. Paris: Gallimard, 1972.

Les mots et les choses. Une archéologie des sciences humaines. Paris: Gallimard, 1966.

FreUd, S. (1895). Esquisse d'une psychologie scientifique. In La naissance de la psychanalyse. Paris: PUF, 1973. pp. 307-386.

. (1915). Vue d'ensemble des névroses de transfert. In OCF.P. Paris: PUF, 1988.

pp. 279-300. v. XIII.

. (1920). Au-delà du principe de plaisir. In Essais de psychanalyse. Paris: Payot. pp. 41-115.

. (1921). Psychologie des masses es analyse du moi. In OCF.P. Paris: PUF, 1991. pp. 1-83. v. XVI.

. (1932). Nouvelles conférences d'íntroduction à la psychanalyse. Paris: Gallimard, 1936.

. (1937). Constructions dans l'analyse. In Résultats, idées, problèmes. Paris: PUF, 1990. pp. 269-281. v. II.

Gagnepain, J. Du vouloir dire. Traité d'épistémologie des sciences humaines. Du signe. De l'outil. Paris: Pergamon, 1982. t. I.

. Du vouloir dire. Traité d'épistémologie des sciences humaines. De la personne. De la norme. Bruxelles: De Boeck, 1991. t. II.

GORI, R. La preuve par la parole. Paris: PUF, 1996. [Trad. bras. A prova pela fala. Sobre a causalidade em psicanálise. São Paulo/Goiânia: Escuta/Ed.Univ. Cat. de Goiás, 1998. . La destitution de la preuve par la parole dans sciences modernes. In P.T.A.H., 43$58,1997$.

. Le sujet en question. In Sciences Sociales et Santé. 16(1): 75-80, 1998a.

L'organe ventriloque. Transfert de pensée et paroles d'organe. International Forum of Psychoanalysis, 1998b.

Hegel, G. W. F. (1807). Phénoménologie de l'esprit. Paris: Aubier, 1975.

HeIDEGGER, M. (1951-52). Qu'appelle-t-on penser? Paris: PUF, 1959.

Kant, I. (1786). Conjectures sur les débuts de l'histoire humaine. In PiobrtTA, S. (ed.). Kant. La philosophie et l'historie (opuscules). Paris: Montaigne-Gonthier, Méditations, 1947. pp. 110-127.

LACAN, J. (1953). Fonction et champ de la parole et du langage en psychanalyse. In Écrits. Paris: Seuil, 1966. pp. 237-322.

MARX, K. (1875). Postface à la seconde édition allemande. In Le capital. Paris: GarnierFlammarion, 1969. t. I.

MAYR, E. (1982). Histoire de la biologie. Diversité, évolution, hérédité. Paris: Fayard, 1989.

Monod, J. Le hasard et la nécessité. Essai sur la philosophe naturelle de la biologie moderne. Paris: Seuil, 1970.

Mettens, P. L'hystérie comme trouble de l'interprétation. In Le Poupon, 1997.

MetTens et al. L'éthique hors la loi. Bruxelles: De Boeck-Université, pp. 141-158. . Sciences cognitives et psychanalyse. Bruxelles: De Boeck, 1988a. 


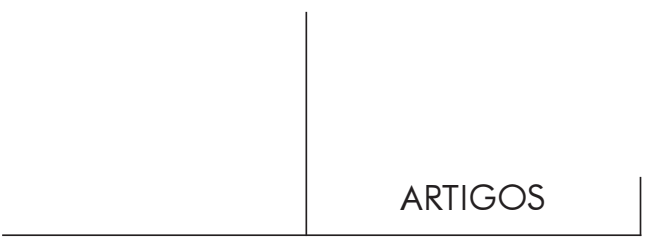

Inconscient psychanalytique et inconscient cognitif. Quelles différences?, 1988b. . \& Gori, R. Quelles (im)postures intellectuelles? A propos de l'écriture et des mathématiques, 1998.

Nietzsche, F. Ainsi parlait Zarathoustra. Paris: Aubier-Flammarion, 1883. t. I.

Pavel, T. Le mirage linguistique. Essai sur la modernisation intellectuelle. Paris: Minuit, 1988.

Ріснот, A. Éléments pour une théorie de la biologie. Paris: Maloine, 1980.

Rostand, J. (1945). Esquisse d'une histoire de la biologie. Paris: La Découverte, 1987. (1954). Pensées d'un biologiste sciences. In Confidences d'un biologiste. Paris:

La Découverte, 1987. pp. 139-172.

(1958). Sciences fausses et fausse sciences. In Confidences d'un biologiste. Paris:

La Découverte, 1987. pp. 139-172.

SAussure, F. de (1916). Cours de linguistique générale. Paris: Payot, 1972.

SoKAL, A.D. Transgressing the boundaries: towards a transformative hermeneutics of quantum gravity. Social Text. (46-47): 217-252, 1996.

\& BRICMONT, J. Impostures intellectuelles. Paris: Odile Jacob, 1997.

Zima, P. V. La déconstruction. Une critique. Paris: PUF, 1994.

\section{Resumos}

En este texto se busca una teorización del sujeto desde la psicoanálisis, del estructuralismo y del pos-modernidad.

Los autores se proponen aquí a mostrar cómo y porque un ocultamento de la cuestión del sujeto vuelve y lleva a las peores derivaciones ideológicas, diluida en un cuerpo cuyo espíritu se ve reducido a una función entre otras o en la masa de individuos orientados a un fin común, eventualmente conflitual. Y toman como hipótesis "mostrar que toda disciplina proyecta sobre la manera en que se desenvolve 'su' ciencia la epistemologia implicita con la cual frecuentemente se sustenta à la revelia”.

Palabras llave: Psicoanálisis, teorización del sujeto, estructuralismo, pos-modernidad

Dans ce texte, on cherche une théorisation du sujet à partir de la psychanalyse, du strucutralisme et de la notion de post-modernité.

Les auteurs se proposent ici a "montrer comment et pourquoi une occultation de la question du sujet y fait incessantement retour et conduit aux pires dérives idéologiques, diluée qu'elle dans un corps dont l'esprit se voit réduit à une fonction parmi d'autres ou dans la masse d'individus orientés vers un but commun, éventuellement conflictuel. Et prennent pour hypothèse "... montrer que toute discipline projette sur la manière dont se développe 'sa' science l'epistémologie implicite dont elle se soutient souvent à son insu”.

Mots clé: Psychanalyse, théorisation du sujet, structuralisme, post-modernité 


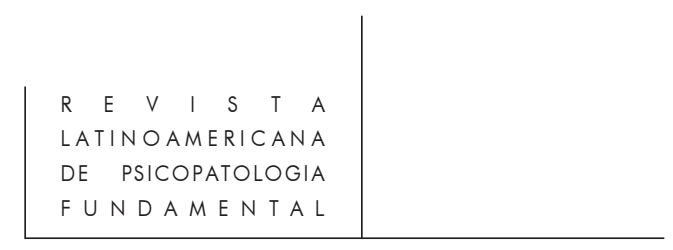

In this text, a theorization of the subject is intended out of the psychoanalysis, the struturalism and the idea of postmodernity.

Herein the authors propose "to show how and why a concealement of the subject issue unceasingly returns and leads to the worst ideological derivations, diluted as it is in a body whose spirit is reduced to one function among others, or in the mass of individuals guided... to a common, occasionally conflictual end". And they assume as hypothesis: "to demonstrate that every discipline projects onto the way "its" science develops the implicit epistemology which often sustains itself in its absence .

Key words: Psychoanalysis, theorization of the subject, struturalism, postmodernity 